\title{
PENGARUH MODEL PEMBELAJARAN IMPROVE BERBANTUAN MASALAH TERBUKA TERHADAP KEMAMPUAN PEMECAHAN MASALAH MATEMATIKA SISWA KELAS VIII SMP LABORATORIUM UNDIKSHA
}

\author{
N. P. S. Jayanti ${ }^{1}$, I. M. Ardana ${ }^{2}$, I. P. P. Suryawan ${ }^{3}$ \\ Jurusan Pendidikan Matematika Universitas Pendidikan Ganesha \\ Singaraja, Indonesia \\ e-mail: jayanti.putu@undiksha.ac.id, ardanaimade@undiksha.ac.id, pasek.suryawan@yahoo.co.id
}

\begin{abstract}
Abstrak
Penelitian ini bertujuan untuk mengetahui apakah kemampuan pemecahan masalah matematika siswa yang mengikuti pembelajaran dengan model pembelajaran IMPROVE berbantuan masalah terbuka lebih baik daripada kemampuan pemecahan masalah matematika siswa yang mengikuti pembelajaran konvensional. Jenis penelitian ini adalah ekperimen semu dengan desain penelitian post test only control group design. Populasi dalam penelitian ini adalah siswa kelas VIII SMP Laboratorium Undiksha tahun ajaran 2018/2019 sebanyak 99 siswa. Pengambilan sampel dilakukan dengan teknik cluster random sampling, diperoleh sampel penelitian sebanyak 49 siswa. Data kemampuan pemecahan masalah siswa dikumpulkan melalui tes uraian yang diberikan kepada siswa di akhir penelitian. Ratarata nilai kemampuan pemecahan masalah matematika siswa yang dibelajarkan dengan model pembelajaran IMPROVE berbantuan masalah terbuka adalah 66,16 dan rata-rata nilai kemampuan pemecahan masalah matematika siswa yang mengikuti pembelajaran konvensional adalah 54. Analisis data menggunakan uji-t satu ekor yaitu ekor kanan, dengan taraf signifikan $5 \%$. Hasil analisis data menunjukkan bahwa nilai thitung $=4,125$ lebih dari tabel $=2,011$. Nilai statistik ini memiliki makna bahwa kemampuan pemecahan matematika siswa mengikuti pembelajaran dengan model pembelajaran IMPROVE berbantuan masalah terbuka lebih baik daripada kemampuan pemecahan masalah matematika siswa yang mengikuti pembelajaran konvensional. Jadi, dapat disimpulkan bahwa penerapan model pembelajaran IMPROVE berbantuan masalah terbuka memiliki pengaruh positif terhadap kemampuan pemecahan masalah matematika siswa
\end{abstract}

Kata kunci: kemampuan pemecahan masalah, model pembelajaran IMPROVE, masalah terbuka

Abstract
This research was aimed to know whether students' problem solving in Mathematics who studied with IMPROVE learning model assisted with open ended-problem was better rather than students who studied with conventional learning. This research was quasi-experimental research with post-test only control group design. The population of this research was the eighth class students of SMP Laboratorium Undiksha 2018/2019 which consisted of 99 students. The sample was collected through cluster random sampling technique, and then the sample of this research was 49 students. The data of students' problem solving was collected through essay test which was given to the students at the end. The average score of students who studied with IMPROVE learning model assisted with open ended-problem was 66.16 and the average score of students who studied with conventional learning was 54.00 . The data were analyzed through one tailed t-test with significant value $5 \%$. The result of the data analysis showed that tobs $=4.125$ is higher than tctv $=2.011$. Therefore, the statistics data mean that students' problem solving in Mathematics who studied with IMPROVE learning model assisted with open ended-problem was better than students' who studied with conventional learning. In conclusion, the implementation of IMPROVE learning model assisted with open ended-problem had positive impact on students math problem solving.

Key words: problem solving ability, IMPROVE learning model, open ended-problem. 


\section{PENDAHULUAN}

Pembelajaran matematika adalah salah satu ilmu dasar yang wajib diajarkan di semua jenjang pendidikan, mulai dari jenjang sekolah dasar hingga perguruan tinggi. Pembelajaran matematika hendaknya dirancang sedemikian rupa sehingga siswa merasa senang, gembira dan tidak merasa tertekan atau terpaksa dalam proses pembelajaran matematika. Kegiatan pembelajaran matematika diharuskan untuk lebih aktif dan kreatif dalam mengembangkan atau menerapkan matematika untuk menyelesaikan permasalahan dalam kehidupan sehari-hari. Penyelesaian permasalahan dalam kehidupan sehari-hari dapat dihubungkan dengan kemampuan pemecahan masalah matematika siswa.

Kemampuan pemecahan masalah adalah suatu proses yang digunakan untuk menyelesaikan masalah. Penyelesaian dari suatu permasalahan merupakan kemampuan seseorang dalam mencapai tujuan yang diharapkan. Hal tersebut menyebabkan kemampuan pemecahan masalah merupakan salah satu kemampuan yang penting untuk dikembangkan dan dimiliki oleh siswa.

Menurut National Council of Teachers of Mathematics (NCTM, 2000) menegaskan pemecahan masalah merupakan bagian integral dalam pembelajaran matematika sehingga hal tersebut tidak boleh dilepaskan dari pembelajaran matematika. Terdapat empat fase dalam memecahkan suatu masalah matematika seperti yang dikemukakan oleh Polya (1954) yaitu, (1) memahami masalah, (2) merencanakan pemecahan, (3) melaksanakan pemecahan dan (4) memeriksa kembali hasil yang telah diperoleh. Kemampuan pemecahan masalah matematika siswa diperlukan adanya suatu masalah yang dapat membuka secara luas wawasan yang dimiliki siswa, serta kemampuan berpikir kritis siswa. Hal tersebut berguna untuk memaksimalkan kemampuan pemecahan masalah matematika siswa.

Kenyataannya

kemampuan

matematika siswa masih rendah, sehingga siswa juga memiliki kemampuan rendah dalam menyelesaikan suatu permasalahan. Hal tersebut tercermin pada rata-rata nilai Ujian Nasional Matematika SMP Se-Bali mengalami penurunan sebesar 2,01 dari tahun sebelumnya. Perubahan terjadi dari 43,63 pada tahun 2017 menjadi 41,62 pada tahun 2018. Jika kemampuan pemecahan masalah matematika siswa rendah, maka siswa tidak akan terampil di dalam memilih dan mengidentifikasi kondisi dan konsep yang relevan, mencari generalisasi, merumuskan rencana penyelesaian serta menggorganisasikan keterampilan yang sudah dimiliki. Jadi rendahnya kemampuan pemecahan masalah matematika siswa sangat berhubungan dengan rendahnya prestasi yang diraih siswa dalam mata pelajaran matematika.

Oleh karena itu pentingnya membangun kemampuan pemecahan masalah dan menuntut adanya model dalam proses pembelajaran matematika. Penerapan model inovatif dan media yang menarik dapat diberikan saat pembelajaran matematika agar lebih efektif, menyenangkan dan siswa lebih tertarik mengikuti pembelajaran matematika.

Penerapan model pembelajaran yang inovatif dan mampu mengakomodir kemampuan pemecahan masalah matematika siswa merupakan salah satu yang tepat dilakukan, salah satu model pembelajaran inovatif yang bisa diterapkan adalah model pembelajaran IMPROVE. IMPROVE merupakan singkatan dari Introducing new concepts (menghantarkan konsep baru), Metacognitive Questioning (pemberian pertanyaan metakognitif), Practicing (berlatih), Reviewing and Reducing Difficulties (mengulas dan mengurangi kesulitan), Obtaining mastery (penguasaan materi), Verification (melakukan verifikasi) dan Enrichment (pengayaan) yang merupakan representasi dari tahapan dalam model pembelajaran ini. Model pembelajaran IMPROVE merupakan suatu model pembelajaran yang inovatif dan didesain untuk meningkatkan penguasaan materi dan mengasah kemampuan pemecahan masalah siswa.

Tahapan-tahapan yang terdapat dalam model pembelajaran IMPROVE memungkinkan siswa untuk lebih bebas dalam menggunakan pengetahuan yang dimiliki dalam menyelesaikan permasalahan sehingga pembelajaran dapat menjadi lebih efektif dan bermakna seperti yang 
dinyatakan dalam penelitian yang sudah pernah dilakukan dengan model pembelajaran IMPROVE.

Penelitian yang sudah pernah dilakukan mengenai pembelajaran IMPROVE adalah penelitian yang dilakukan oleh Ira Dewi Ilham pada tahun 2017 menyatakan dalam proses belajar matematika siswa mampu berinteraksi dan meningkatkan kemampuan penalarannya dengan model pembelajaran IMPROVE sehingga memberikan pengaruh positif terhadap kemampuan penalaran matematis siswa, maka akan berpengaruh positif pula pada kemampuan pemecahan masalah. Nur Rafida Herawati pada tahun 2015 menyatakan dalam proses belajar siswa yang mampu meningkatkan keaktifan dan kemampuan pemahaman konsep matematika dengan baik, secara tidak langsung akan berpengaruh pada kemampuan pemecahan masalah matematika..

Penelitian yang sudah pernah dilakukan menyatakan bahwa model pembelajaran IMPROVE berpengaruh positif terhadap kemampuan pemecahan masalah. Pada langkah Metacognitive Questioning guru diharuskan mempunyai strategi serta pertanyaan yang dapat membangkitkan kreatifitas siswa. Menurut Srini (2014) kegiatan metakognitif sangat penting karena dapat melatih siswa untuk berpikir tingkat tinggi serta mampu merencanakan, mengontrol dan merefleksi segala aktivitas berpikir yang telah dilakukan. Penggunaan proses metakognitif selama pembelajaran, akan membantu siswa agar mampu memperoleh pembelajaran yang bertahan lama dalam ingatan dan pemahaman siswa. Srini (2014) juga menyatakan kegiatankegiatan metakognitif dimunculkan melalui empat situasi, yaitu: (1) siswa diminta untuk menjustifikasi suatu kesimpulan atau mempertahankan sanggahan; (2) situasi kognitif dalam menghadapi suatu masalah membuka peluang untuk merumuskan pertanyaan; (3) siswa diminta untuk membuat kesimpulan, pertimbangan dan keputusan yang benar sehingga diperlukan kehati-hatian dalam memantau dan mengatur proses kognitifnya; dan (4) situasi siswa dalam kegiatan kognitif memahami kesulitan, misalnya dalam pemecahan masalah.

Sehubungan dengan hal tersebut, untuk memaksimalkan penerapan model pembelajaran IMPROVE terutama pada langkah Metacognitive Questioning dalam memaksimalkan kemampuan pemecahan masalah matematika, maka alangkah lebih baik model ini dibantu dengan masalah terbuka. Pembelajaran dengan menggunakan masalah terbuka akan membuat kegiatan pembelajaran menjadi lebih bersifat student oriented. Pada proses pembelajaran siswa mendapat kesempatan untuk menginvestigasi berbagai strategi dan cara yang diyakininya, sehingga siswa dapat mengekspresikan ide-idenya. Siswa memiliki kesempatan lebih banyak memanfaatkan pengetahuan dan keterampilan matematis secara komprehensif dan membuat siswa yang mempunyai kemampuan rendah dapat merespon permasalahan dengan caranya sendiri. Selain menguntungkan bagi siswa, dengan menggunakan masalah terbuka juga memberikan kesempatan bagi guru untuk melakukan bimbingan baik yang bersifat individu ataupun kelompok, sehingga diharapkan dapat menumbuhkan kemandirian siswa, meningkatkan motivasi belajar siswa serta kemampuan pemecahan masalah matematika siswa.

Mengakomodasi untuk memaksimalkan kemampuan pemecahan masalah matematika dapat dilakukan dengan pemberian masalah matematika terbuka. Masalah terbuka merupakan masalah yang menuntut pemahaman konsep siswa. Menurut Sudiarta (2003) masalah terbuka dalam pembelajaran matematika merupakan masalah atau soalsoal matematika yang dirumuskan sedemikian rupa, sehingga memiliki banyak cara atau solusi yang benar dan terdapat banyak cara penyelesaian untuk mencari solusi tersebut.

Peneliti menduga bahwa penggunaan masalah terbuka dalam pembelajaran matematika dapat memaksimalkan pengaruh dari model pembelajaran IMPROVE terhadap kemampuan pemecahan masalah matematika siswa serta memberikan suatu inovasi baru dalam proses pembelajaran. Selain itu, sejauh pengetahuan peneliti, belum terdapat kajian 
yang memadai mengenai pengaruh model pembelajaran IMPROVE yang dibantu dengan masalah terbuka dalam pembelajaran matematika terhadap kemampuan pemecahan masalah matematika siswa. Berdasarkan rasional ini, maka. peneliti memandang perlu untuk memberikan kontribusi ilmiah dalam bentuk penelitian yang berjudul "Pengaruh Model Pembelajaran IMPROVE Berbantuan Masalah Terbuka Terhadap Kemampuan Pemecahan Masalah Matematika Siswa Kelas VIII SMP Laboratorium Undiksha".

\section{METODE}

Jenis penelitian ini adalah penelitian eksperimen yaitu eksperimen semu (quasi experiment). karena peneliti tidak dapat mengontrol kondisi dan variabel-variabel lain yang dapat mempengaruhi pelaksanaan penelitian. Penelitian eksperimen ini bertujuan untuk menguji pengaruh variabelvariabel bebas terhadap variabel terikat yaitu untuk mencari pengaruh model pembelajaran IMPROVE berbantuan masalah terbuka terhadap kemampuan pemecahan masalah matematika siswa. Desain penelitian yang digunakan adalah "post test only control group design".

Populasi dalam penelitian ini adalah seluruh siswa kelas VIII SMP Laboratorium Undiksha yang terdiri dari 4 kelas dengan total 99 siswa. Teknik pengambilan sampel dalam penelitian ini menggunakan cluster random sampling dengan sistem pengundian. Dari hasil pengundian terpilih dua kelas yakni kelas VIII 2 dan VIII 4. Sebelum diundi untuk menentukan kelas eksperimen dan kelas kontrol, terlebih dahulu dilakukan uji kesetaraan sampel dengan menganalisis nilai ulangan umum semester genap siswa menggunakan rumus uji-t.

Berdasarkan hasil analisis diperoleh bahwa tidak terdapat perbedaan kemampuan awal siswa kelas VIII 2 dan kelas VIII 4 SMP Laboratorium Undiksha atau dapat dikatakan bahwa sampel memiliki kemampuan yang setara. Selanjutnya kedua kelas tersebut diundi untuk menentukan kelas eksperimen dan kelas kontrol. Hasil undi menunjukkan bahwa kelas VIII 2 sebagai kelas eksperimen yang diberikan perlakuan dengan penerapan model pembelajaran IMPROVE berbantuan masalah terbuka dan kelas VIII 4 sebagai kelas kontrol yang diberikan perlakuan dengan pembelajaran konvensional. Pembelajaran konvensional yang dimaksud adalah pembelajaran langsung.

Penelitian ini melibatkan variabel bebas dan variabel terikat. Variabel bebas dalam penelitian ini adalah model pembelajaran. Adapun variabel terikat dalam penelitian ini adalah kemampuan pemecahan masalah matematika siswa.

"Instrumen penelitian adalah alat yang digunakan oleh peneliti untuk mengumpulkan data" (Arikunto, 2006:160). Instrumen penelitian ini bertujuan untuk mengetahui kemampuan pemecahan masalah matematika siswa. Dalam pengumpulan data tersebut diperlukan sebuah instrumen penelitian berupa tes pemecahan masalah matematika dan tes yang digunakan adalah tes uraian (essay). Hal ini bertujuan agar seluruh indikator kemampuan pemecahan masalah matematika dapat tercapai.

Setelah siswa diberikan tes kemampuan pemecahan masalah matematika siswa, selanjutnya dilakukan pengujian hipotesis yang diajukan. Terlebih dahulu, data yang diperoleh dilakukan uji prasyarat yakni uji normalitas menggunakan Lilliefors dan uji homogenitas varians dengan menggunakan uji-F. Selanjutnya, hipotesis dilakukan dengan menggunakan uji-t satu ekor (ekor kanan). Adapun rumus untuk uji-t satu ekor (ekor kanar) dalam penelitian ini adalah sebagai berikut.

$$
\begin{aligned}
& t_{\text {hit }}=\frac{\bar{Y}_{1}-\bar{Y}_{2}}{s \sqrt{\frac{1}{n_{1}}+\frac{1}{n_{2}}}} \\
& \text { Dengan : } \\
& S^{2}=\frac{\left(n_{1}-1\right) S_{1}^{2}+\left(n_{2}-1\right) S_{2}^{2}}{\left(n_{1}+n_{2}-2\right)}
\end{aligned}
$$

(Candiasa, 2010b: 58)

Keterangan:

$\bar{Y}_{1}=$ rata-rata skor dari Kelas eksperimen

$\overline{Y_{2}}=$ rata-rata skor dari Kelas kontrol

$S^{2}=$ simpangan baku gabungan

$S_{1}=$ simpangan baku dari Kelas eksperimen

$S_{2}=$ simpangan baku dari Kelas kontrol

$n_{1}=$ banyak subjek dari Kelas eksperimen 
$n_{2}=$ banyak subjek dari Kelas kontrol

Kriteria pengujian adalah tolak $H_{0}$ jika

$t_{h i t} \geq t_{(1-\alpha)}$, dimana $t_{(1-\alpha)}$ didapat dari tabel

distribusi $t$ pada taraf signifikasi $\alpha=5 \%$

dengan derajat kebebasan (dk) = $\left(n_{1}+n_{2}-2\right)$

\section{HASIL PENELITIAN}

Hasil penelitian ini berupa data nilai tes kemampuan pemecahan masalah matematika siswa sebagai dampak dari penerapan model pembelajaran IMPROVE berbantuan masalah terbuka pada kelompok ekperimen dan pembelajaran konvensional pada kelompok kontrol. Nilai pemecahan masalah matematika siswa diperoleh melalui post-test untuk kelompok eksperimen dan control. Rangkuman hasil analisis data kemampuan pemecahan masalah matematika siswa pada kelompok eksperimen dan kontrol disajikan pada Tabel 1.

Berdasarkan Tabel 1. terlihat bahwa bahwa rata-rata nilai kemampuan pemecahan masalah matematika siswa yang mengikuti pembelajaan dengan model pembelajaran IMPROVE berbantuan masalah terbuka pada kelompok eksperimen lebih tinggi daripada rata-rata nilai kemampuan pemecahan masalah matematika siswa kelompok kontrol yang mengikuti pembelajaran konvensional.

Tabel 1. Hasil Analisis Data

\begin{tabular}{ccc}
\hline \multirow{2}{*}{ Variabel } & \multicolumn{2}{c}{ Sampel } \\
\cline { 2 - 3 } & $\begin{array}{c}\text { Kelas } \\
\text { Ekperimen }\end{array}$ & $\begin{array}{c}\text { Kelas } \\
\text { Kontrol }\end{array}$ \\
\hline Banyak Siswa $(n)$ & 25 & 24 \\
\hline Rata-rata $(\bar{X})$ & 66,16 & 54 \\
\hline Standar Deviasi $(S D)$ & 10.566 & 10.043 \\
\hline
\end{tabular}

Sebelum melakukan pengujian hipotesis terlebih dahulu dilakukan uji prasyarat analisis yaitu uji normalitas dan uji homogenitas. Rangkuman hasil uji normalitas kelas eksperimen dan kontrol dapat dilihat pada Tabel 2 .
Berdasarkan Tabel 2, dapat dilihat bahwa $L_{\text {hitung }}$ pada kedua kelompok sampel, baik kelompok eksperimen maupun kelompok kontrol kurang dari $L_{\text {tabel }}$ pada kelompok yang bersangkutan.

Tabel 2. Rangkuman Hasil Uji Normalitas

\begin{tabular}{cccc}
\hline Kelas Sampel & $\mathbf{L}_{\text {hitung }}$ & $\mathbf{L}_{\text {tabel }}$ & Ket \\
\hline Eksperimen & 0,1020163 & 0,173 & Normal \\
\hline Kontrol & 0,1204755 & 0,173 & Normal \\
\hline
\end{tabular}

Dengan demikian $\mathrm{H}_{0}$ diterima dengan taraf signifikan 5\%, hal ini berarti data kemampuan pemecahan masalah matematika siswa berdistribusi normal.

Setelah menguji normalitas data kemudian akan diuji homogenitas terhadap varians pasangan antar kelompok eksperimen dan kontrol. Uji yang digunakan adalah uji- $F$ dengan kriteria data homogen jika $F_{\text {hitung }}<F_{\text {tabel. }}$ Rangkuman hasil uji homogenitas varians antar kelompok eksperimen dan kelompok kontrol disajikan pada Tabel 3.

Berdasarkan Tabel 3 dapat dilihat bahwa $F_{\text {hitung }}<\mathrm{F}_{\text {tabel}}$, sehingga $\mathrm{H}_{0}$ diterima. Hal ini berarti nilai kemampuan koneksi matematis siswa di kelas eksperimen dan kelas kontrol memiliki varians data homogen

\section{Tabel 3. Rangkuman Hasil Homogenitas}




\begin{tabular}{llccc}
\hline $\begin{array}{l}\text { Varians } \\
\text { Terbesar }\end{array}$ & $\begin{array}{l}\text { Varians } \\
\text { Terkecil }\end{array}$ & $\begin{array}{c}\text { F }=\begin{array}{c}\text { Varians } \\
\text { Terbesar } \\
\text { Varians } \\
\text { Terkecil }\end{array} \\
\text { F Tabel }\end{array}$ & Kriteria \\
\hline 100,8695652 & 111,64 & 0,903525306 & 2,005009458 & HOMOGEN \\
\hline
\end{tabular}

- Berdasarkan hasil uji prasyarat yang telah dilakukan, diperoleh hasil bahwa nilai kemampuan pemecahan masalah matematika siswa berdistribusi normal dan memiliki varians yang homogen sehingga pengujian hipotesis penelitian dapat dilakukan. Pengujian hipotesis dilakukan dengan menggunakan uji-t satu ekor (ekor kanan) dengan taraf signifikansi 5\%. Adapun rangkuman hasil pengujian hipotesis penelitian disajikan pada Tabel 4 .

Tabel 4. Rangkuman Hasil Uji Hipotesis

\begin{tabular}{lcccccc}
\hline Kelompok & $\mathbf{n}$ & Rata-rata & $\boldsymbol{S}^{\mathbf{2}}$ & $\left(\boldsymbol{S}_{\text {gab }}\right)^{\mathbf{2}}$ & $\boldsymbol{t}_{\text {hitung }}$ & $\boldsymbol{t}_{\text {tabel }}$ \\
\hline Eksperimen & 25 & 66,16 & 111,64 & \multirow{2}{*}{106,37} & 4,125 & 2.011 \\
\hline Kontrol & 24 & 54 & 100,87 & & & \\
\hline
\end{tabular}

Berdasarkan hasil perhitungan pada Tabel 4 , diperoleh bahwa nilai $t_{\text {hitung }}>t_{\text {tabel }}$, sehingga $\mathrm{H}_{0}$ ditolak dengan taraf signifikansi $5 \%$. Hal ini berarti, kemampuan pemecahan masalah matematika siswa yang mengikuti pembelajaran dengan model pembelajaran IMPROVE berbantuan masalah terbuka lebih baik daripada kemampuan pemecahan masalah matematika siswa yang mengikuti pembelajaran konvensional.

\section{PEMBAHASAN}

Hasil analisis nilai didapatkan bahwa rata-rata nilai kemampuan pemecahan masalah matematika siswa yang dibelajarkan dengan model pembelajaran IMPROVE berbantuan masalah terbuka yaitu 66,16 lebih tinggi daripada rata-rata nilai kemampuan pemecahan masalah matematika siswa yang dibelajarkan dengan pembelajaran konvensional yaitu 54. Hasil tersebut diperoleh dari jumlah nilai post test yang diberikan dibagi banyak siswa. Hal ini menunjukkan bahwa rata-rata nilai kemampuan pemecahan masalah matematika pada kelompok ekperimen lebih tinggi dibandingkan dengan rata-rata nilai kemampuan pemecahan masalah matematika kelompok kontrol. Hasil uji hipotesis menggunakan uji-t satu ekor kanan diperoleh bahwa $t_{\text {hitung }}=4,125>t_{\text {tabel }}=2,011$ untuk $\alpha=5 \%$ sehingga $\mathrm{HO}$ ditolak dan $\mathrm{H} 1$ diterima. Ini berarti bahwa kemampuan pemecahan masalah matematika siswa
Kelas VIII SMP Laboratorium Undiksha yang mengikuti pembelajaran dengan model pembelajaran IMPROVE berbantuan masalah terbuka lebih baik dari kemampuan pemecahan masalah matematika siswa yang mengikuti model pembelajaran konvensional.

Berdasarkan hasil pengamatan yang dilakukan peneliti, model pembelajan IMPROVE berbantuan masalah terbuka dalam proses pembelajaran dapat mengefektifkan proses diskusi kelompok, karena setiap masalah terbuka yang diberikan membuat siswa mempunyai banyak kesempatan dalam menjawab dan bertanya. Hal tersebut sejalan dengan pendapat Japa dan Suarjana, 2012:79 menyatakan bahwa secara konseptual, masalah terbuka dalam pembelajaran matematika adalah "masalah atau soal-soal matematika yang dirumuskan sedemikian rupa, sehingga memiliki beberapa solusi bahkan banyak solusi yang benar dan terdapat banyak cara untuk mencari solusi tersebut". Sedangkan dalam pembelajaran yang menggunakan model pembelajaran konvensional, siswa mencatat yang dijelaskan secara langsung oleh guru dan mengerjakan LKS dengan membagi tugas dengan tujuan mempercepat proses pengerjaan. Hal tersebut menyebabkan orientasi siswa dalam belajar menjadi berubah, bukannya untuk memahami atau menguasai materi yang diajarkan melainkan 
hanya ingin cepat dalam menyelesaikan permasalahan yang ada tanpa memaksimalkan kesempatan berdiskusi yang ada.

Langkah-langkah

model

pembelajaran IMPROVE berbantuan masalah terbuka melatih siswa untuk membangun sendiri pemahamannya terhadap apa yang sedang dipelajari dan dapat menanggapi setiap permasalahan yang ada. Peneliti sebagai fasilitator mengantarkan konsep baru (introducing new concepts) dengan pertanyaan-pertanyaan pancingan yang membuat siswa secara aktif dalam menemukan konsep baru dengan menggunakan bahasa sendiri. Siswa dalam menyatakan ulang konsep dengan bahasa sendiri, siswa diberikan pertanyaan metakognitif (metacognitive questioning). Pertanyaan metakognitif adalah pertanyaan yang dapat berupa pertanyaan pemecahan masalah, pertanyaan koneksi dan pertanyaan strategi. Pemberian pertanyaan metakognitif ini dibantu dengan LKS yang berisikan masalah terbuka. Siswa dihadapkan dengan masalah terbuka, tujuan utamanya bukan untuk mendapatkan jawaban tetapi lebih menekankan pada cara menyampaikan suatu jawaban. Dengan demikian bukan hanya satu pendekatan atau metode dalam mendapatkan jawaban, namun beberapa atau banyak.

Nohda (dalam Suherman, dkk, 2003:124) menyatakan bahwa tujuan dari pembelajaran masalah terbuka adalah untuk membantu mengembangkan kegiatan kreatif dan pola pikir matematika siswa. Siswa berkesempatan untuk berpikir kreatif dalam berpendapat dan bertanya yang sama dalam kelompoknya maupun pada saat diskusi dengan kelompok lain. Hal tersebut membuat siswa dilatih untuk dapat berpikir secara kritis dan sistematis untuk melatih pola pikir matematika dalam mengaitkan pengetahuan yang sudah ada dengan pengetahuan baru didapatkannya. Sejalan dengan pendapat Ormrod (2010) menyatakan bahwa pemecahan masalah adalah menggunakan (mentransfer) pengetahuan dan keterampilan yang sudah ada untuk menjawab pertanyaan yang belum terjawab dalam situasi yang sulit.

Pada tahap practicing siswa dilatih untuk memecahkan masalah. Latihan soal merupakan strategi untuk memperkuat proses akomodasi pemahaman konsep yang diterapkan dalam pemecahan masalah. Latihan diberikan dengan masalah terbuka dapat membantu mengembangkan kegiatan kreatif dan pola pikir matematika siswa sehingga mampu melatih siswa dalam meningkatkan kemampuan pemecahan masalah. Menyelesaikan masalah yang dilakukan siswa tidak luput dari kesulitan dan kesalahan yang dialami siswa. Pada tahap reviewing and reducing difficulities, peneliti mengulas dan meninjau ulang jawaban penyelesaian yang dibuat siswa untuk memastikan pemahaman siswa terhadap suatu konsep dalam penyelesaiaan masalah sudah benar atau sebaliknya. Perwakian setiap kelompok diberikan kesempatan untuk mempresentasikan hasil diskusi yang diperoleh pada saat latihan. Perbedaan pendapat dan hasil jawaban dari masalah terbuka yang diberikan pada masing-masing kelompok menyebabkan diskusi antar kelompok terjadi. Hal tersebut membuat situasi pembelajaran aktif dan melatih siswa dalam mengemukakan pendapatnya. Apabila secara umum kelas mengalami kesulitan maka melalui diskusi peneliti memberikan solusi atau perbaikan untuk mengurangi kesulitan yang dihadapi siswa.

Tahap selanjutnya adalah obtaining mastery tahap siswa diberikan tes untuk mengetahui penguasaan materi yang dialami siswa. Hasil tes tersebut dapat menakar penguasaan materi siswa baik secara individu maupun secara keseluruhan. Tes yang diberikan sesuai dengan materi yang dipelajari untuk mengukur kemampuan pemecahan masalah matematika siswa. Melalui hasil tes dapat diketehui siswa yang belum atau sudah menguasai materi sehingga dapat dilakukan verification untuk mengidentifikasi siswa yang sudah mencapai batas kelulusan dan siswa yang belum mencapai batas kelulusan. Tahap terakhir adalah enrichment yang mencangkup dua jenis kegiatan yaitu perbaikan dan pengayaan. Kegiatan perbaikan diberikan kepada siswa yang belum mencapai batas kelulusan untuk membantu siswa dalam memperbaiki kesalahan konsep dari materi ajar serta kemampuan pemecahan masalah. Kegiatan 
pengayaan diberikan kepada siswa yang sudah mencapai batas kelulusan untuk memberikan kesempatan mengoptimalkan kemampuannya melalui pemberian soal-soal aplikasi dari materi yang telah dikuasai.

Hasil analisis tes kemampuan pemecahan masalah matematika siswa menunjukkan bahwa siswa yang mengikuti pembelajaran dengan model pembelajaran IMPROVE berbantuan masalah terbuka lebih baik dibandingkan dengan siswa yang mengikuti pembelajaran konvensional. Hal tersebut dikarenakan dengan menerapkan model pembelajaran IMPROVE berbantuan masalah terbuka seperti yang dipaparkan diatas siswa terbiasa berdiskusi dalam kelompoknya, menemukan konsep baru, menyelesaikan pertanyaan metakognitif yang diberikan dengan LKS berisikan masalah terbuka didukung dengan latihan sehingga dapat memantapkan kemampuan dalam memecahkan masalah matematika siswa.

Hal ini sejalan dengan penelitian Desi Ariani pada tahun 2014 yang menunjukkan bahwa open-ended problem memberikan pengaruh yang signifikan terhadap kemampuan pemecahan masalah. Hasil penelitian juga sejalan dengan yang dilakukan Nur Rafida pada tahun 2015 yang menyatakan bahwa model pembelajaran IMPROVE dalam proses belajar siswa mampu meningkatkan keaktifan dan kemampuan pemahaman konsep matematika dengan baik, secara tidak langsung akan berpengaruh terhadap kemampuan pemecahan masalah matematika siswa. Akan tetapi hasil penelitian ini bertentangan dengan penelitian yang dilakukan oleh Komang Gunawan, 2013 menyimpulkan dalam penelitiannya tidak ada perbedaan antara aktivitas siswa yang dibelajarkan dengan model IMPROVE dengan model berbasis inkuiri dengan aktivitas siswa yang dibelajarkan dengan metode ceramah dengan modul berbasis inkuiri, yaitu sama-sama berada pada katagori baik. Hal ini disebabkan pada kelas ekperimen dan kelas kontrol pada penelitian Komang Gunawan, 2013 siswa sama-sama diberikan bahan ajar berupa modul berbasis inkuiri yang membuat siswa menjadi aktif dikelas. Karena penelitian Komang Gunawan, 2013 memiliki dua variable yang telah diuji dan hasil dari pembelajaran dengan mengunakan model pembelajaran IMPROVE dengan modul inkuiri dapat menyebabkan hasil belajar kognitif siswa mencapai KKM dan lebih baik daripada model belajar biasa yang biasa dilakukan disekolah dengan modul berbasis inkuiri. Akan tetapi rata-rata nilai dari kelas ekperimen lebih rendah daripada kelas kontrol untuk aktivitas siswanya, sedangkan rata-rata nilai untuk hasil belajar kelas ekperimen lebih tinggi daripada kelas kontrol. Jika menggunakan model pembelajaran IMPROVE ada langkah yang akan membuat siswa lebih aktif daripada siswa yang dibelajarkan dengan model ceramah yaitu langkah introducing new concept dan metakognitif questioning. Langkah tersebut guru berperan mengarahkan siswa untuk menemukan konsep baru dan menjawab pertanyaan metakognitif, melalui langkah tersebut dapat mengaktifkan aktivitas belajar siswa. Sedangkan dalam penelitian yang dilakukan oleh peneliti adanya perbedaan antara siswa yang mengikuti pembelajaran dengan model pembelajaran IMPROVE berbatuan masalah terbuka lebih baik daripada siswa yang dibelajarkan dengan model pembelajaran konvensional.

Secara umum, pelaksanaan dengan model pembelajaran IMPROVE berbantuan masalah terbuka dapat berjalan baik sesuai rencana. Walaupun demikian, dalam pelaksanannya di kelas tidak luput dari adanya kendala-kendala. Adapun kendalakendala yang dihadapi adalah sebagai berikut.

1. Memerlukan manajemen waktu yang baik dalam persiapan maupun pelaksanaan proses pembelajaran dengan menggunakan model pembelajaran IMPROVE. Hal ini disebabkan karena kemampuan peserta didik tidak sama dalam menyelesaikan permasalahan ataupun menjawab pertanyaan yang diberikan sehingga diperlukan bantuan dan bimbingan khusus oleh guru. Hal ini mengakibatkan waktu yang diperlukan untuk menyelesaikan materi cukup lama.

2. Siswa merasa kebingungan saat model ini pertama kali diterapkan sehingga siswa memerlukan waktu untuk terbiasa. 
Oleh karena itu, diperlukan upaya ekstra diawal pembelajaran agar maksud model pembelajaran dapat dipahami siswa.

3. Pada saat perwakilan kelompok diminta untuk mempresentasikan hasil diskusi di depan kelas, siswa masih terlihat malumalu untuk menyampaikan kepada siswa lain. Pada awal pertemuan hanya sedikit siswa yang berani mengajukan pertanyaan.

Namun kendala-kendala tersebut dapat ditangani dengan baik. Kendalakendala tersebut dapat ditangani dengan membatasi waktu untuk masing-masing kegiatan agar tidak terjadi kekurangan waktu selama proses pembelajaran. Kemudian, pada setiap awal pertemuan guru harus mengingatkan kembali tahapan-tahapan pembelajaran yang harus dilakukan oleh siswa. Yang terakhir adalah dengan memberikan motivasi kepada siswa dengan memberikan petunjuk berupa pernyataan atau pertanyaan yang membuat siswa terpacu lebih aktif dalah tahap diskusi. Selain itu, dengan mewajibkan setiap kelompok mengajukan pertanyaan pada awal-awal pertemuan akan memberikan tanggung jawab kepada siswa untuk bertanya sehingga siswa akan semakin terpacu untuk memahami materi dan pada akhirnya mendorong siswa lebih aktif mengajukan pertanyaan.

Secara umum dapat diberikan kesimpulan bahwa model pembelajaran IMPROVE berbantuan masalah terbuka lebih baik digunakan untuk menanamkan kemampuan pemecahan masalah matematika siswa dibandingkan dengan pembelajaran konvensional. Hal tersebut juga didukung oelh hasil uji hipotesis yang menunjukkan kemampuan pemecahan masalah matematika siswa yang mengikuti pembelajaran dengan model pembelajaran IMPROVE berbantuan masalah terbuka lebih baik daripada kemampuan pemecahan masalah matematika siswa yang mengikuti pembelajaran konvensional. Melihat kontribusi positif tersebut, diharapkan model pembelajaran IMPROVE berbantuan masalah terbuka dapat dikembangkan dan diterapkan dalam proses pembelajaran khususnya proses pembelajaran matematika di Indonesia.

\section{SIMPULAN DAN SARAN}

Berdasarkan pembahasan hasil penelitian dan hasil uji hipotesis, dapat diambil simpulan bahwa kemampuan pemecahan masalah matematika siswa yang mengikuti pembelajaran dengan model pembelajaran IMPROVE berbantuan masalah terbuka lebih baik daripada kemampuan pemecahan masalah matematika yang mengikuti pembelajaran konvensional. Dengan kata lain model pembelajaran IMPROVE berbantuan masalah terbuka berpengaruh positif terhadap kemampuan pemecahan masalah matematika siswa.

Adapun saran yang dapat disampaikan berdasarkan hasil penelitian yang telah dilaksanakan adalah sebagai berikut.

1. Kepada praktisi pendidikan matematika, khususnya guru mata pelajaran matematika diharapkan untuk menerapkan model pembelajaran IMPROVE berbantuan masalah terbuka sebagai salah satu alternatif pembelajaran dalam kegiatan pembelajaran di kelas mengingat memberikan pengaruh positif terhadap kemampuan pemecahan masalah matematika siswa.

2. Penelitian ini dilakukan hanya sebatas untuk mengetahui kemampuan pemecahan masalah matematika siswa dan materi pembelajaran yang terbatas. Para peneliti lain disarankan untuk melakukan penelitian pada aspek pembelajaran matematika lainnya dan materi pembelajaran yang lebih luas untuk mengetahui pengaruh pembelajaran ini dalam pembelajaran matematika secara lebih mendalam

\section{DAFTAR PUSTAKA}

Ariani, Desi, Candiasa, dan Marhaeni. (2014). Pengaruh implementasi open-ended problem dalam pembelajaran matematika terhadap kemampuan pemecahan masalah matematis dengan pengendalian kemampuan penalaran abstrak. EJurnal Program Pascasarjana Universitas Pendidikan Ganesha 
Program Studi Penelitian dan Evaluasi Pendidikan. Volume 4.

Arianto, I Komang Gunawan. 2013. Pengaruh Model IMPROVE dengan Modul Berbasis Inkuiri terhadap Aktivitas dan Hasil Belajar Kognitif Siswa. FPMIPA IKIP Mataram Jurusan Pendidikan Kimia.

Arikunto, Suharsimi. 2006. Prosedur Penelitian Suatu Pendekatan Praktik (Edisi Revisi VI). Jakarta: PT Rineka Cipta.

Candiasa, I Made. 2010b. Statistik Univariat dan Bivariat disertai Aplikasi SPSS. Singaraja: Unit Penerbitan Undiksha.

Herawati, Nur Rafida. 2015. Penerapan Model Pembelajaran IMPROVE Untuk Meningkatkan Keaktifan dan Pemahaman Konsep Matematika Siswa Kelas X MIA 1 SMA Negeri 1 Sukoharjo Tahun Pelajaran 2013/2014. Universitas Sebelas Maret Fakultas Keguruan dan IImu Pendidikan.

Ilham. Ira Dewi. 2017. Penerapan Model Pembelajaran IMPROVE Dalam Upaya Meningkatkan Kemampuan Penalaran Matematis Siswa Kelas VIII. SESIOMADIKA Universitas Singaperbangsa Karawang, Pendidikan Matematika Fakultas Keguruan dan IImu Pendidikan.

Japa, I Gusti Ngurah \& I Made Suarjana. 2012. Pembelajaran Matematika SD. Singaraja: Universitas Pendidikan Ganesha.

Mavarech, Z. R. dan Kramarski, B. (1997). IMPROVE: A Multimedimentional Method for Teaching Mathematics in Heterogeneous classroom, American Educational Research Jurnal, 34 (2)

Ormrod, Jeanne Ellis. 2010. Psikologi Pendidikan Membantu Siswa Tumbuh dan Berkembang. University of New Hampshire. Jakarta: Erlangga.
Polya, Grorge. 1954. Mathematics and Plausible Reasoning.Vol I, New Jersey: Princenton University Press.

Sudiarta, I Gusti. P. 2003. Pembangunan Konsep Matematika Melalui "OpenEnded Problem": Studi Kasus pada Sekolah Dasar Elisabeth Osnabrueck Jerman. Oktober 2003. Jurnal Pendidikan dan Pengajaran IKIP Negeri Singaraja.

Suherman, E. dkk. 2003. Strategi Pembelajaran Matematika Kontemporer (Common Textbook Edisi Revisi). Bandung: Universitas Pendidikan Indonesia. 